\title{
A Comparison Among Different Parameters for the Design of a Photovoltaic/Thermal System Using Computational Fluid Dynamics
}

\author{
Payman Salami \\ Department of Biosystems \\ Engineering, Faculty of \\ Agriculture, University of \\ Tabriz, Iran \\ salami@ut.ac.ir
}

\author{
Yahya Ajabshirchi \\ Department of Biosystems \\ Engineering, Faculty of \\ Agriculture, University of \\ Tabriz, Iran \\ yajabshir@tabrizu.ac.ir
}

\author{
Shamsollah Abdollahpoor \\ Department of Biosystems \\ Engineering, Faculty of \\ Agriculture, University of \\ Tabriz, Iran \\ Shamstabriz1@yahoo.com
}

\author{
Hossein Behfar \\ Department of Biosystems \\ Engineering, Faculty of \\ Agriculture, University of \\ Tabriz, Iran \\ behfar@tabrizu.ac.ir
}

\begin{abstract}
The purpose of this paper is to compare several fins, duct height, and velocity magnitudes to acquire a PhotoVoltaic/Thermal system designed through Computational Fluid Dynamics. Simulation of different fins (rectangular, trapezoidal, curved, and pin) with different distances among fins is performed in Fluent software. The parameters such as duct height $(4,6,8$, and 10 centimeters) and velocity magnitudes $(0.5$, 1,2 , and $3 \mathrm{~m} / \mathrm{s}$ ) are also simulated. According to the results the highest cell temperature was $51^{\circ} \mathrm{C}$ at $0.5 \mathrm{~m} / \mathrm{s}$, while the best result was $33^{\circ} \mathrm{C}$ achieved with $4 \mathrm{~cm}$ duct height, rectangular fin and 3 $\mathrm{m} / \mathrm{s}$ velocity magnitude. The findings suggest that the maximum cell temperature at the rate of $0.5 \mathrm{~m} / \mathrm{s}$ is $51{ }^{\circ} \mathrm{C}$, whereas temperature conducive to the best outputs is $33^{\circ} \mathrm{C}$. Differences among the cell temperatures through the various duct and the different fin types were significant at $1 \%$ level, also velocity magnitude would be cardinal at $1 \%$ level. A logarithmic regression model has been proposed to getting the cell temperature estimated by velocity magnitude.
\end{abstract}

Keywords-Computational Fluid Dynamics (CFD); Energy Efficiency; Fin; PhotoVoltaic/Thermal (PV/T)

\section{INTRODUCTION}

In a hybrid photovoltaic/thermal (PV/T) solar collector, the PV cells are combined with a solar thermal unit as a composite absorber and thus electricity and heat from the absorbed solar radiation would be generated simultaneously. Most of the absorbed solar radiation by the PV modules is converted into waste heat since the cell's conversion efficiencies are currently low [1] and this heat manifests itself as a temperature rise of the module. The high temperature has a negative effect on the electrical output of the PV module, especially in case of the dominant crystalline Si based cells [2], where their conversion efficiency degrades by about $0.4-0.5 \%$ per degree rise in temperature [3-4] and a form of cooling is rather beneficial.

Due to the aforementioned temperature influence on the performance of PV cells, the energy that is not converted into electricity by the PV cells must be extracted to prevent excessive cell heating and the caused deteriorated performance. Therefore, solar cell cooling must be an integral part of PV systems, especially in concentrated PV designs in order to minimize the effect of elevated temperatures on the PV module power output [5].

As a matter of fact, the high temperature would be affecting the electrical output of a PV module in a negative way gradually, especially with cells made from Si crystalline, so it must be stated that just this very factor could reduce conversion efficiency about $0.4-0.5 \%$ per degree rise in temperature, but laying within cool status to be beneficial. Performance is a crucial characteristic during the constructing of solar panels. Augmenting the performance brings about thwarting amount of exorbitant and energy loss. PV cells have got the potential to be extremely efficient. It should not be forgotten that just these lucrative sets might have born a performance about $28.9 \%$, ever in the worst case scenario [6].

As known PV cells performance of this appliance is directly related to their temperature, so electrical efficiency could be calculated as deduction of mean temperature of $\mathrm{PV} / \mathrm{T}$ and Nominal Operating Cell Temperature (NOCT). The relationship between efficiency and temperature are shown in (1) and it is assumed that there would be a $0.45 \% / 0 \mathrm{C}$ decrease in electrical efficiency [7-8].

$$
\eta_{e l}=\eta_{o p}\left(1-0.0045\left(T_{m p}-N O C T\right)\right)
$$

where $\eta_{o p}$ is the nominal efficiency of the photovoltaic cell at the Nominal Operating Cell Temperature (NOCT) and $\eta_{e l}$ is the efficiency of the photovoltaic cell at the mean absorber temperature $T_{m p}$.

Hegazy examined four types of PVT air heating solar collectors using a numerical model [9]. The systems in the study utilized a glass cover mounted above the PV module thus forming a second air gap. This is commonly used on collectors for solar water heating to reduce convection heat losses from 
the top surface of the collector plate. Hegazy found that getting the air circulated between the back surface of the module and the isolating layer as well as at the top of module surface and the glass cover might offer the best balance between electrical and thermal performance.

Some results in [10] demonstrated what were extracted by Hegazy. Both studies utilized a static reflector plate that conducted solar radiation from an area with same size as PVT through their collector therefore just this would offer a concentration ratio of approximately 1.3 . They found that an unglazed PVT collector had a maximum thermal efficiency of $38 \%$. Glazing the system or adding the static reflector could increase the performance about $60 \%$, if both glazing and adding the reflector to be fulfilled the efficiency would possibly reach $75 \%$. It was also noted however, that although glazing improved the thermal efficiency it tended to increase optical losses, resulting in a decreased electrical efficiency.

Some studies have let cooling flat plate PV modules examined, for instance in [11-12] it was proposed that exploiting some simple low cost alterations might improve the performance of PVT air heaters. It was shown that adding fins to the rear part of the PV modules could optimize the PVT system performance. It was suggested that Hegazy's technique along with adding a flimsy metal sheet in the air passage behind the PV module would improve the thermal and electrical efficiency.

One of the ways to upturn the heat transfer process is by utilizing an extending effective plane by which the contact surface with the working fluid would be increased automatically. In [13], several PV-T air collectors with additional fins at the backside of the absorber collector were developed. The fins brought about an increase in total efficiency from 49.1 to 62.8 percent. In [14], a PV-T air collector with $\mathrm{V}$-groves to increase the absorber surface and thus the heat transfer process was proposed [14].

\section{MATERIALS AND METHODS}

Computational Fluid Dynamics (CFD) is a robust technique used to solving Navier- Stokes equations numerically, based on a finite volume approach. Using the Fluent computational fluid dynamics (CFD) software, some series of simulations with different configurations of fins were performed. In the case of Forced convection, the fluid flow was modeled for the air flowing underneath the solar panel. Due to the complicated nature of fluid flow and fins, a three dimensional model was originated for each case. The design of the 3D models was conducted in AutoCAD and model meshing was done in Gambit. The motion of fluid, heat transfer (which gives temperature distribution) and turbulence are calculated. The discrete scheme for the momentum and energy equations adopted the second order upwind. The criterion of convergence for terminating the iteration is $10^{-3}$ for the momentum equation and $10^{-6}$ for the energy equation. Through inlet, the air pressure would be imagined as uniform and constant value. SIMPLE (Semi Implicit Method for Pressure Linked Equations) was adopted [15]. The standard $\mathrm{k}-\varepsilon$ turbulence model was used to estimating the turbulence [16].
The hydraulic diameter $\left(D_{h}\right)$, the Nusselt number $\left(N u_{x}\right)$, and the Reynolds number (Re) for non-circular ducts are expressed, respectively below $[15,17]$ :

$$
\begin{aligned}
& D_{h}=\frac{4 A_{C}}{P} \\
& N u_{x}=\frac{h(x) D_{h}}{k} \\
& \operatorname{Re}=\frac{u_{m} \cdot D_{h}}{v}
\end{aligned}
$$

where $A_{c}$ is the cross sectional area, $P$ is the wetted perimeter, $h(x)$ is the local heat transfer coefficient, $k$ is the thermal conductivity, $u_{m}$ is the mean velocity, and $v$ is the kinematic viscosity.

To obtain the minimum cell temperature, different designs were simulated in Fluent. Different fins (rectangular, trapezoidal, curved) and pin with different distances from fins were considered (Figure 1). Four types of duct heights $(4,6,8$, and 10 centimeters) were assessed. Four types of velocity magnitudes $(0.5,1,2$, and $3 \mathrm{~m} / \mathrm{s})$ were simulated. Through the simulation process the ambient temperature and solar irradiation were assumed to be $30^{\circ} \mathrm{C}$ and $900 \mathrm{~W} / \mathrm{m}^{2}$ respectively. The aim of this study is to compare different fins, duct height and velocity magnitudes. The differences among cell temperatures for the levels of the three factors were investigated by univariate analysis of variance at the $5 \%$ and $1 \%$ significance level.

\section{RESULTS AND DISCUSSION}

Results show that the highest cell temperature would be $51{ }^{\circ} \mathrm{C}$ at a velocity magnitude of $0.5 \mathrm{~m} / \mathrm{s}$. Increased velocity magnitudes would decrease the cell temperature significantly. Table I shows the cell temperature at $0.5 \mathrm{~m} / \mathrm{s}$ velocity magnitude, whereas Tables II, III and IV show the cell temperature at $1 \mathrm{~m} / \mathrm{s}, 2 \mathrm{~m} / \mathrm{s}$ and $3 \mathrm{~m} / \mathrm{s}$ velocity magnitudes respectively. The best result was for $4 \mathrm{~cm}$ duct height, rectangular fin and $3 \mathrm{~m} / \mathrm{s}$ velocity magnitude $\left(33^{\circ} \mathrm{C}\right)$, but it's difference with the $2 \mathrm{~m} / \mathrm{s}$ velocity magnitude is not considerable (only $1^{\circ} \mathrm{C}$ ) and thus the excess energy to cool the panel would probably prove to be not affordable. According to (1), in the absence of forced convection, the efficiency might decrease about $3.6 \%$. As the solar irradiation was assumed to be $900 \mathrm{~W} / \mathrm{m}^{2}$, the total waste of energy in this case is about $32.4 \mathrm{~W} / \mathrm{m}^{2}$.

Obviously, based on the univariate analysis of variance (Table V), the difference among cell temperatures at the different duct heights is significant at $1 \%$ level. However the cell temperature at the $4 \mathrm{~cm}$ duct height is lower than other duct heights. Also the difference among cell temperatures at the different fin types is significant at $1 \%$ level, but what to be considerable is that, the cell temperature at the rectangular fins is lower than other fin types. Like these two factors, some element playing a pivotal role in boosting cell temperature and the difference among cell temperatures at different velocity 
magnitudes at is significant $1 \%$ level. Also the interactions of all of two way factors is significant at $1 \%$ level.

As shown, the main factor which affects the cell temperature is the velocity magnitude. A regression model to estimate the cell temperature $(\mathrm{T})$ by velocity magnitude $(\mathrm{V})$ is shown in (5). The R square for the linear model was 0.659 and for the logarithmic model was 0.736 . The velocity magnitude and cell temperature diagram for the linear and logarithmic models is shown in Figure 2.

$$
T=-5.352 \times \ln (V)+41.283
$$
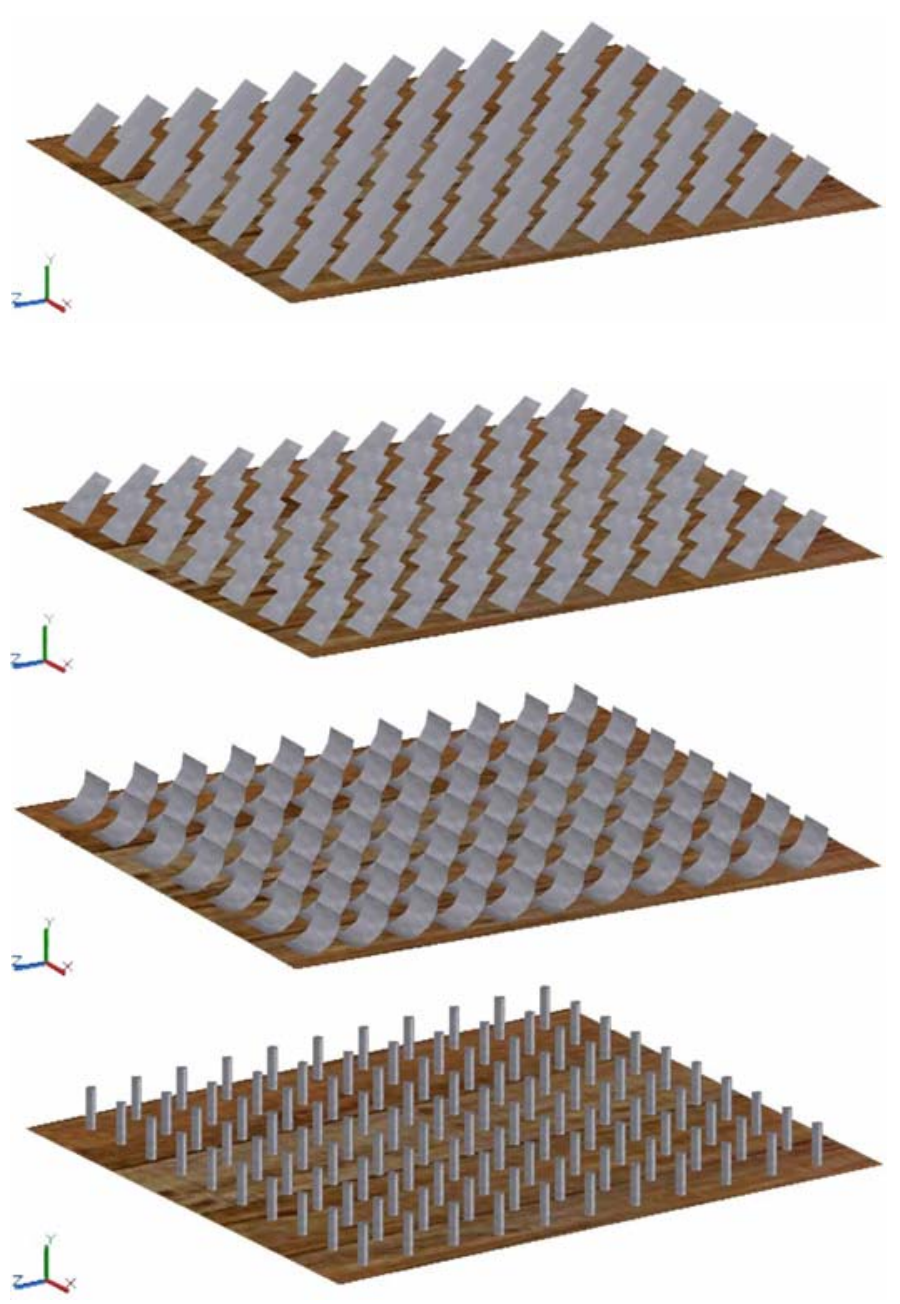

Fig. 1. Fin types (rectangular, trapezoidal, curved, and pin)

TABLE I. CELL TEMPERATURE AT $0.5 \mathrm{~m} / \mathrm{s}$ VELOCITY MAGNITUDE

\begin{tabular}{|c|c|c|c|c|}
\hline $\begin{array}{c}\text { Duct height } \\
\text { Fin type }\end{array}$ & $\mathbf{4}$ & $\mathbf{6}$ & $\mathbf{8}$ & $\mathbf{1 0}$ \\
\hline No fin & 44 & 46 & 49 & 51 \\
\hline Rectangular & 42 & 44 & 44 & 47 \\
\hline Trapezoidal & 41 & 44 & 46 & 47 \\
\hline Curved & 41 & 43 & 45 & 48 \\
\hline Pin & 43 & 45 & 48 & 50 \\
\hline
\end{tabular}

TABLE II. CELL TEMPERATURE AT $1 \mathrm{~m} / \mathrm{s}$ VELOCITY MAGNITUDE

\begin{tabular}{|c|c|c|c|c|}
\hline $\begin{array}{c}\text { Duct height } \\
\text { Fin type }\end{array}$ & $\mathbf{4}$ & $\mathbf{6}$ & $\mathbf{8}$ & $\mathbf{1 0}$ \\
\hline No fin & 41 & 42 & 44 & 45 \\
\hline Rectangular & 37 & 38 & 39 & 41 \\
\hline Trapezoidal & 38 & 39 & 41 & 41 \\
\hline Curved & 38 & 39 & 40 & 42 \\
\hline Pin & 40 & 41 & 43 & 45 \\
\hline
\end{tabular}

TABLE III. Cell temperature AT $2 \mathrm{~m} / \mathrm{s}$ Velocity Magnitude

\begin{tabular}{|c|c|c|c|c|}
\hline $\begin{array}{c}\text { Duct height } \\
\text { Fin type }\end{array}$ & $\mathbf{4}$ & $\mathbf{6}$ & $\mathbf{8}$ & $\mathbf{1 0}$ \\
\hline No fin & 37 & 39 & 40 & 41 \\
\hline Rectangular & 34 & 36 & 36 & 38 \\
\hline Trapezoidal & 35 & 36 & 37 & 38 \\
\hline Curved & 35 & 36 & 37 & 38 \\
\hline Pin & 37 & 38 & 39 & 40 \\
\hline
\end{tabular}

TABLE IV. CELl temperature AT $3 \mathrm{~m} / \mathrm{s}$ VELOCITY MAGNitude

\begin{tabular}{|c|c|c|c|c|}
\hline $\begin{array}{c}\text { Duct height } \\
\text { Fin type }\end{array}$ & $\mathbf{4}$ & $\mathbf{6}$ & $\mathbf{8}$ & $\mathbf{1 0}$ \\
\hline No fin & 36 & 37 & 38 & 39 \\
\hline Rectangular & 33 & 34 & 35 & 36 \\
\hline Trapezoidal & 34 & 35 & 36 & 36 \\
\hline Curved & 34 & 34 & 36 & 37 \\
\hline Pin & 35 & 36 & 37 & 38 \\
\hline
\end{tabular}

TABLE V. UNIVARIATE ANALYSIS OF VARIANCE FOR CELL TEMPERATURE

\begin{tabular}{|c|c|c|c|c|c|}
\hline \multicolumn{6}{|c|}{ Dependent Variable: Cell Temperature } \\
\hline Source & $\begin{array}{l}\text { Type III Sum } \\
\text { of Squares }\end{array}$ & df & $\begin{array}{l}\text { Mean } \\
\text { Square }\end{array}$ & $\mathrm{F}$ & Sig. \\
\hline $\begin{array}{c}\text { Corrected } \\
\text { Model }\end{array}$ & $1446.66^{\mathrm{a}}$ & 43 & 33.64 & 219.21 & $\begin{array}{c}0.00 \\
0\end{array}$ \\
\hline Intercept & 126802.81 & 1 & 126802.81 & 826226.47 & $\begin{array}{c}0.00 \\
0\end{array}$ \\
\hline $\begin{array}{c}\text { Duct } \\
\text { Height }\end{array}$ & 191.84 & 3 & 63.95 & 416.66 & $\begin{array}{c}0.00 \\
0\end{array}$ \\
\hline Fin Type & 140.13 & 4 & 35.03 & 228.26 & $\begin{array}{c}0.00 \\
0\end{array}$ \\
\hline Velocity & 1083.44 & 3 & 361.15 & 2353.17 & $\begin{array}{c}0.00 \\
0\end{array}$ \\
\hline $\begin{array}{c}\text { Duct } \\
\text { Height * } \\
\text { Fin Type }\end{array}$ & 5.48 & 12 & 0.46 & 2.97 & $\begin{array}{c}0.00 \\
6\end{array}$ \\
\hline $\begin{array}{c}\text { Duct } \\
\text { Height } * \\
\text { Velocity } \\
\end{array}$ & 20.91 & 9 & 2.32 & 15.14 & $\begin{array}{c}0.00 \\
0\end{array}$ \\
\hline $\begin{array}{l}\text { Fin Type } \\
* \text { Velocity }\end{array}$ & 4.88 & 12 & 0.41 & 2.65 & $\begin{array}{c}0.01 \\
0\end{array}$ \\
\hline Error & 5.53 & 36 & 0.15 & & \\
\hline Total & 128255.00 & 80 & & & \\
\hline $\begin{array}{c}\text { Corrected } \\
\text { Total }\end{array}$ & 1452.19 & 79 & & & \\
\hline
\end{tabular}




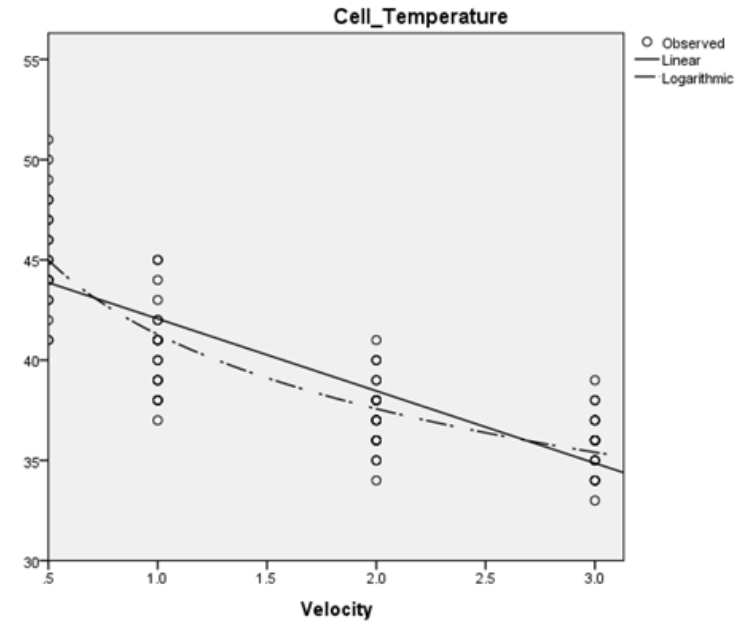

Fig. 2. The velocity magnitude and cell temperature diagram for the linear and logarithmic models

To validate the simulation results, experimental data were obtained from 2nd April 2016 to 9th April 2016 at the University of Tabriz, Iran. The average of ambient temperature and solar irradiation were $14.6^{\circ} \mathrm{C}$ and the $751 \mathrm{~W} / \mathrm{m}^{2}$ respectively. The experimental data was obtained from $4 \mathrm{~cm}$ duct height, rectangular fins and also the average velocity magnitude of the fan was $1 \mathrm{~m} / \mathrm{s}$. The experimental results showed that the average cell temperature was $22^{\circ} \mathrm{C}$. As the ambient temperature for the primary simulation and solar radiation were assumed $30^{\circ} \mathrm{C}$ and $900 \mathrm{~W} / \mathrm{m}^{2}$ respectively, so another simulation based on the experimental condition whose temperature was $21^{\circ} \mathrm{C}$ was fulfilled. Let's say the simulation data could show the realistic situation (i.e. experimental data) and $1{ }^{\circ} \mathrm{C}$ is the thermal difference between.

In [18], an air-based PV/T solar collector which applied two low cost approaches to enhance heat transfer between the air flow and PV surface was constructed. A finned metal sheet was attained to the back wall of the air-channel to improve heat extraction from the PV modules. The experimental tests were carried out on the air-based PV/T system which used a $46 \mathrm{Wp}$ rated commercial pc-Si PV module and has $0.4 \mathrm{~m}^{2}$ of aperture area as the absorber plate. The results showed good agreement between predicted values and measured data. It is found that the induced mass flow rate and thermal efficiency decrease with increasing ambient (inlet) temperature and increase with increasing tilt angle for a given insulation level. The results also showed that the optimum channel depth occurs between $0.05 \mathrm{~m}$ and $0.1 \mathrm{~m}$ for this system. This type of PV/T system is practical and cost effective, suitable for being integrated into buildings with both heat and electrical demands.

In [19], it was mentioned that an augmented duct depth from 0.01 to 0.1 could get the thermal efficiency and outlet air temperature decreased. These characteristics may be attributed to the decreasing absorber to air heat transfer coefficients and the reduction of the radiative heat transfer coefficient for the double-glass configuration. Since solar cell efficiency is strongly dependent on solar cell temperature, it also decreases with an increase in duct depth and a decrease in collector length. Therefore, system efficiency which is a sum of thermal and electrical efficiencies, also decreases with an increase in duct depth and a decrease in collector length.

According to the results of this study, the best duct height among $4,6,8$, and $10 \mathrm{~cm}$ is $4 \mathrm{~cm}$ which is consistent with [18, 19]. In [20], the performance of a double pass PV/T solar air heater with and without fins was examined. It was found that the extended fin area reduced the cell temperature considerably, from $82^{\circ} \mathrm{C}$ to $66^{\circ} \mathrm{C}$. This somehow contradicts the results of this study, as the maximum difference found in this study was only $5{ }^{\circ} \mathrm{C}$. In $[20\}$, it was also mentioned that the relationship between cell temperature and solar radiance is linear (i.e. increasing the cell temperature gets solar radiation increased on the collector surface). The increase in cell temperature with solar irradiance is significant at low flow rates $(0.03 \mathrm{~kg} / \mathrm{s})$ compared to high flow rates $(0.15 \mathrm{~kg} / \mathrm{s})$. Boosting the cell temperature at low air flow rates $(0.03 \mathrm{~kg} / \mathrm{s})$ reduces the thermal and electrical efficiencies of the PV/T air collector. It is shown that the velocity magnitude has a strong impact on the cell temperature. The distribution of the data are shown in Figure 3.

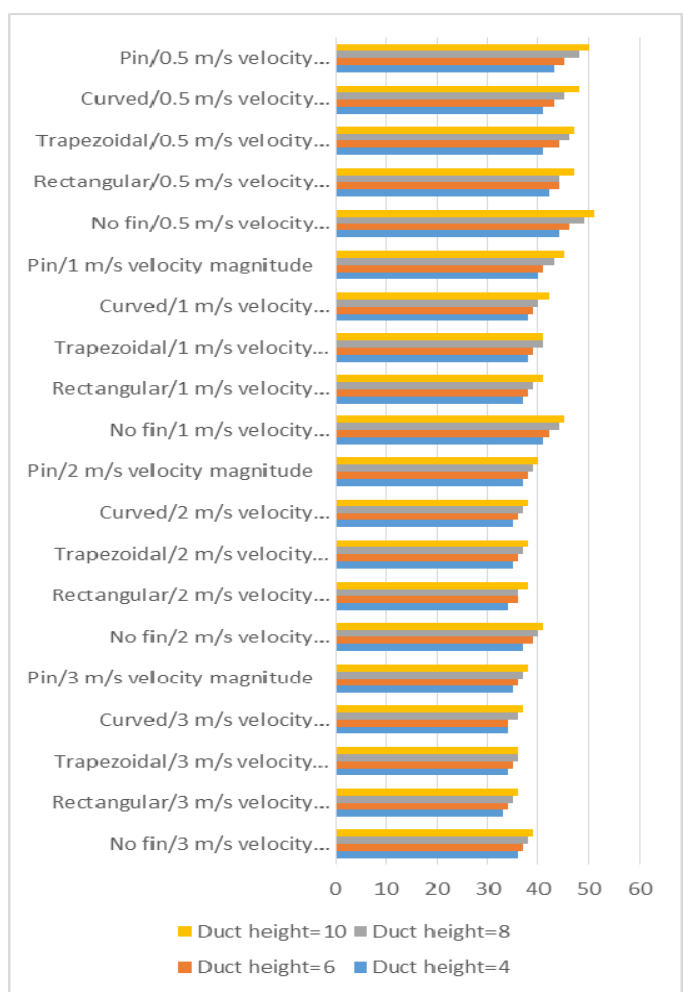

Fig. 3. The distribution of the data chart

\section{CONCLUSION}

The objective of this study was getting a detailed comparison among various fins, ducts heights and velocity magnitudes to gain the minimum cell temperature. The results show that the highest cell temperature is $51^{\circ} \mathrm{C}$ at $0.5 \mathrm{~m} / \mathrm{s}$ velocity magnitude, while the best result is laid at $4 \mathrm{~cm}$ duct height, rectangular fin and $3 \mathrm{~m} / \mathrm{s}$ velocity magnitude $\left(33^{\circ} \mathrm{C}\right)$. The difference among cell temperatures at the different duct 
heights and fin types are significant at 1\% level, also it is significant for the different velocity magnitudes at $1 \%$ level. A logarithmic regression model was presented to estimate the cell temperature using velocity magnitude.

\section{REFERENCES}

[1] J. K. Tonui, Y. Tripanagnostopoulos, "Performance improvement of PV/T solar collectors with natural air flow operation”, Solar Energy, Vol. 82, pp. 1-12, 2008

[2] P. D. Maycock, "PV review, World solar PV market continues explosive growth", Refocus, Vol. 16, pp. 105-145, 2005

[3] B. J. Brinkworth, B. M. Cross, R. H. Marshall, H. Yang, "Thermal regulation of photovoltaic cladding", Solar Energy, Vol. 61, pp. 169178, 1997

[4] S. Krauter, R. G. Arauja, S. Schroer, R. Hanitsh, M. J. Salhi, C. Triebel, R. Lemoine, "Combined photovoltaic and solar thermal systems for facade integration and building insulation", Solar Energy, Vol. 67, pp. 239-248, 1999

[5] S. Chatterjee, G. Tamizh Mani, "BAPV arrays: side-by-side comparison with and without fan cooling", IEEE Photovoltaic Specialists Conference (PVSC), Vol. 7, pp. 537-542, 2011

[6] M. J. Y. Tayebjee, L. C. Hirst, N. J. Ekins-Daukes, T. W. Schmidt, "The efficiency limit of solar cells with molecular absorbers: a master equation approach", Journal of Applied Physics, Vol. 108, Art. No. 124506,2010

[7] L. Nishioka, T. Hatayama, Y. Uraoka, T. Fuyuki, R. Hagihara, M. Watanabe, "Field-test analysis of PVsystem output characteristics focusing on module temperature", Solar Energy Materials \& Solar Cells, Vol. 75, No. 3, pp. 665-671, 2003

[8] H. A. Zondag, D. W. de Vries, W. G. J. van Helden, R. J. C. van Zolengen, A. A. van Steenhoven, "The thermal and electrical yield of a PV-thermal collector", Solar Energy, Vol. 72, pp. 113-128, 2002

[9] A. A. Hegazy, "Comparative study of the performances of four photovoltaic/thermal solar air collectors", Energy Conversion and Management, Vol. 41, No. 8, pp. 861-881, 2000
[10] Y. Tripanagnostopoulos, T. Nousia, M. Souliotis, P. Yianoulis, "Hybrid photovoltaic/thermal solar systems", Solar Energy, Vol. 72, No. 3, pp. 217-234, 2002

[11] J. K. Tonui, Y. Tripanagnostopoulos, "Improved PV/T solar collectors with heat extraction by forced or natural air circulation", Renewable Energy, Vol. 32, No. 4, pp. 623-637, 2007

[12] J. K. Tonui, Y. Tripanagnostopoulos, "Air-cooled PV/T solar collectors with low cost performance improvements", Solar Energy, Vol. 81, No. 4, pp. 498-511, 2007

[13] M. Alfegi, K. Sopian, M. Othman, B. Yatim, "Experimental investigation of single pass, double duct photovoltaic thermal (PV/T) air collector with CPC and fins", American Journal of Applied Sciences, Vol. 5, pp. 866-871, 2008

[14] M. Othman, K. Sopian, B. Yatim, W. Daud, "Development of advanced solar assisted drying systems", Renewable Energy, Vol. 31, pp. 703-709, 2006

[15] O. Turgut, "Numerical investigation of laminar flow and heat transfer in hexagonal ducts under isothermal and constant Heat flux boundary conditions", Transactions of Mechanical Engineering, Vol. 38, No. M1, pp. 45-56, 2013

[16] D. M. Hargreaves, N. G. Wright, "On the use of the $k-\varepsilon$ model in commercial CFD software to model the neutral atmospheric boundary layer", Journal of Wind Engineering and Industrial Aerodynamics, Vol. 95, pp. 355-369, 2007

[17] J. G. Jiang, Z. X. Yuan, G. D. Xia, "Periodical heat transfer in parallelplate channel of improved flow-inclining inserts", International Journal of Thermal Sciences, Vol. 48, pp. 1748-1754, 2009

[18] J. K. Tonui, Y. Tripanagnostopoulos, "Performance improvement of PV/T solar collectors with natural air flow operation", Solar Energy, Vol. 82, pp. 1-12, 2008

[19] H. P. Garg, R. S. Adhikari, "Conventional hybrid photovoltaic/thermal $(\mathrm{PV} / \mathrm{T})$ air heating collectors: steady-state simulation", Renewable Energy, Vol. 11, No. 3, pp. 363-385, 1997

[20] R. Kumar, M. A. Rosen, "Performance evaluation of a double pass PV/T solar air heater with and without fins", Applied Thermal Engineering, Vol. 31, pp. 1402-1410, 2011 